\title{
Utility of conventional clinical risk scores in a low-risk COVID-19 cohort
}

Jinghao Nicholas Ngiam ${ }^{1 \dagger}$, Nicholas W. S. Chew ${ }^{2 \dagger}$, Sai Meng Tham³ , Zhen Yu Lim', Tony Y. W. Li', Shuyun Cen', Paul Anantharajah Tambyah 3,5,6, Amelia Santosa ${ }^{4}$, Ching-Hui Sia ${ }^{2,5}$ and Gail Brenda Cross ${ }^{3, *^{*}}$

\begin{abstract}
Background: Several specific risk scores for Coronavirus disease 2019 (COVID-19) involving clinical and biochemical parameters have been developed from higher-risk patients, in addition to validating well-established pneumonia risk scores. We compared multiple risk scores in predicting more severe disease in a cohort of young patients with few comorbid illnesses. Accurately predicting the progression of COVID-19 may guide triage and therapy.

Methods: We retrospectively examined 554 hospitalised COVID-19 patients in Singapore. The CURB-65 score, Pneumonia Severity Index (PSI), ISARIC 4C prognostic score (4C), $\mathrm{CHA}_{2} \mathrm{DS}_{2}$-VASC score, COVID-GRAM Critical Illness risk score (COVID-GRAM), Veterans Health Administration COVID-19 index for COVID-19 Mortality (VACO), and the "ruleof-6" score were compared for three performance characteristics: the need for supplemental oxygen, intensive care admission and mechanical ventilation.

Results: A majority of patients were young ( $\leq 40$ years, $n=372,67.1 \%) .57$ (10.3\%) developed pneumonia, with 16 (2.9\% of study population) requiring supplemental oxygen. 19 patients (3.4\%) required intensive care and 2 patients $(0.5 \%)$ died. The clinical risk scores predicted patients who required supplemental oxygenation and intensive care well. Adding the presence of fever to the $\mathrm{CHA}_{2} \mathrm{DS}_{2}$-VASc score and $4 \mathrm{C}$ score improved the ability to predict patients who required supplemental oxygen (c-statistic $0.81,95 \% \mathrm{Cl} 0.68-0.94$; and $0.84,95 \% \mathrm{Cl} 0.75-0.94$ respectively).
\end{abstract}

Conclusion: Simple scores including well established pneumonia risk scores can help predict progression of COVID19. Adding the presence of fever as a parameter to the $\mathrm{CHA}_{2} \mathrm{DS}_{2}-\mathrm{VASC}$ or the $4 \mathrm{C}$ score improved the performance of these scores in a young population with few comorbidities.

Keywords: COVID-19, Risk score, Outcomes, Fever, Singapore

\section{Background}

The pandemic of Coronavirus disease 2019 (COVID-19) has left the entire globe reeling, with almost 2 million lives lost worldwide as of February 2021, and an economic and social fall-out that is yet to be fully realised

\footnotetext{
*Correspondence: mdcgbc@nus.edu.sg

${ }^{\dagger}$ Jinghao Nicholas Ngiam and Nicholas W. S. Chew contributed equally to the manuscript

${ }^{3}$ Department of Infectious Diseases, National University Health System,

1 E Kent Ridge Rd, NUHS Tower Block, Level 10, Singapore 119228,

Singapore

Full list of author information is available at the end of the article
}

[1]. Despite the shocking amount of death and morbidity from this disease, it is estimated up to $80 \%$ of patients have mild disease or are asymptomatic, with $14 \%$ having severe disease including pneumonia and the remaining 5\% with critical illness including multi-organ failure (MOF), septic shock, respiratory failure which can progress to death [2]. Amongst those with moderate to critical illness, the natural history of the disease is such that patients first develop a respiratory illness, typically with a fever, which then progresses in the second week of illness to the development of a pulmonary infiltrate, and in a proportion, this then progresses to the development of 
acute respiratory distress syndrome (ARDS) and MOF [3]. Risk scores developed and utilised thus far have focused on predicting which patients who develop severe to critical disease and would benefit from intensive care therapies [4-6].

It may, however, be more useful to discover a risk score which can predict those who progress to needing the earlier stage of oxygenation, when the initiation of COVID19 specific therapies have more utility. Therapies such as dexamethasone and intravenous remdesivir have been shown to confer survival benefit in patient groups with moderate to severe disease which requires supplemental oxygen [7-9]. Thus far the COVID-19 specific risk scores developed require several laboratory parameters or complicated clinical parameter calculations [10-13], yet a simple tool that did not require laboratory parameters would be of greater utility particularly in an emergency room or clinic setting, especially in low and middle income countries.

\section{Methods}

We examined the first 554 confirmed consecutive patients with reverse transcriptase-polymerase chain reaction (RT-PCR) proven COVID-19 admitted to a single tertiary institution in Singapore from 23rd January 2020 to 30th April 2020. No patients were lost to followup or excluded from the analyses.

We retrospectively collected data on the demographic background (age, gender), medical co-morbidities, clinical profile (symptom status and clinical presentation), baseline haematological and biochemical parameters within $24 \mathrm{~h}$ of admission for each patient. Clinical outcomes were also examined during each patient's hospital stay, including the development of pneumonia, need for supplemental oxygen, need for intensive care, mechanical ventilation and mortality. We have published the demographic profile of this cohort previously and shown that there was a shift from an older, local population with more comorbidities who were at risk of severe disease to a young, migrant worker population with few comorbidities who largely had mild disease [14]. Having noticed that age was a common variable identified in all the risk scores examined, in this current study, we present the analysis of the same cohort stratified within three age bands (40 years or less, 41-64 years of age and those greater than 65 years of age). The age cut-off of 40 was defined by Singapore's Ministry of Health (based on unpublished aggregate data from Singapore COVID-19 cases) to identify those who were at higher risk of severe COVID-19 illness, and who thus required isolation for the first week of illness in hospitals, rather than in community isolation facilities. Later on, this cut-off was lowered further to 30 years of age [15]. Globally, the age group of patients below 40 has also been found to have the lowest mortality as well [16]. The age of 65 was used as a second cut-off since mortality risk increased significantly at and above this age [17].

For each patient, we tabulated information on medical-comorbidities, clinical disease presentation, laboratory results at baseline and clinical outcomes and each of 7 clinical risk scores. We compared risk scores that had been designed in community acquired pneumonia, such as the CURB-65 score [5], and pneumonia severity index [6], as well as scores specifically derived in the context of COVID-19, such as the 4C score [10], "rule-of-6" score [11], VACO score [12], and COVIDGRAM score [13]. In addition, we also examined the $\mathrm{CHA}_{2} \mathrm{DS}_{2}$-VASc score [4], which has been demonstrated to correlate with adverse outcomes in COVID19 cohorts $[18,19]$. Day of illness refers to the number of days post illness onset to hospital admission. Pneumonia was defined as the presence of an infiltrate seen a chest radiograph or computed tomography. Persistent fever was defined as a fever $\geq 72$-h, to define the subset amongst our low-risk cohort with greater risk of severe illness, as previously shown [3]. Thus, we added the presence of fever (1 point) to the $\mathrm{CHA}_{2} \mathrm{DS}_{2}$-VASc score and $4 \mathrm{C}$ score (existing clinical risk scores), and sought to explore if this would improve the ability score to predict adverse outcomes.

To compare the three age categories, one-way analysis of variance (ANOVA) was used for continuous parameters, with the data presented as mean $( \pm$ standard deviation). Kruskal-Wallis or Chi-squared tests for association (where appropriate) were used for categorical parameters, with the data presented as frequencies and percentages. Risk scores for the overall potential and each age category was presented as median score with the corresponding interquartile range. Performance of each risk score in identifying patients who required supplemental oxygen, intensive care admission and mechanical ventilation were assessed by means of area of receiver operating characteristic curve (AUC).

A p-value of less than 0.05 was considered significant. Data analysis was done on SPSS version 20.0 (SPSS, Inc., Chicago, Illinois). Ethics approval was obtained from the hospital's institutional review board (National Healthcare Group (NHG) Domain Specific Review Board (DSRB) 2020/00545) prior to its conduct. Data collected was anonymised and a waiver of informed consent was obtained. Study methods were carried out in accordance with guidelines and regulations by the Declaration of Helsinki and DSRB. 
Table 1 Clinical profile of hospitalized patients with COVID-19 by three age categories

\begin{tabular}{|c|c|c|c|c|c|}
\hline Parameter & Overall $(n=554)$ & Age $\leq 40$ years $(n=372)$ & $\begin{array}{l}\text { Age } 41 \text { to } 64 \text { years } \\
(n=166)\end{array}$ & Age $\geq 65$ years $(n=16)$ & p-value \\
\hline Age (years) & $37( \pm 12)$ & $30( \pm 5)$ & $49( \pm 6)$ & $71( \pm 6)$ & $<0.001$ \\
\hline Gender (Male) & $477(86.9 \%)$ & $327(88.9 \%)$ & $139(83.7 \%)$ & $12(75.0 \%)$ & 0.096 \\
\hline \multicolumn{6}{|l|}{ Medical co-morbidities } \\
\hline $\begin{array}{l}\text { Prior history of hyperten- } \\
\text { sion }\end{array}$ & $53(12.3 \%)$ & $8(2.8 \%)$ & $34(25.2 \%)$ & $11(68.8 \%)$ & $<0.001$ \\
\hline $\begin{array}{l}\text { Prior history of hyperlipi- } \\
\text { daemia }\end{array}$ & $34(8.1 \%)$ & $2(0.7 \%)$ & $20(15.6 \%)$ & $12(75.0 \%)$ & $<0.001$ \\
\hline $\begin{array}{l}\text { Prior history of diabetes } \\
\text { mellitus }\end{array}$ & $21(5.1 \%)$ & $3(1.1 \%)$ & $14(11.2 \%)$ & $4(25.0 \%)$ & $<0.001$ \\
\hline Prior history of asthma & $6(1.5 \%)$ & $4(1.4 \%)$ & $2(1.7 \%)$ & $0(0.0 \%)$ & 0.946 \\
\hline \multicolumn{6}{|l|}{ Clinical profile } \\
\hline Asymptomatic illness & $66(11.9 \%)$ & $52(14.0 \%)$ & $14(8.4 \%)$ & $0(0.0 \%)$ & 0.061 \\
\hline $\begin{array}{l}\text { Day of illness at presenta- } \\
\text { tion }\end{array}$ & $3.5( \pm 5.1)$ & $3.1( \pm 5.0)$ & $4.0( \pm 5.1)$ & $6.8( \pm 5.0)$ & 0.005 \\
\hline Length of days with fever & $1.2( \pm 2.4)$ & $1.0( \pm 2.2)$ & $1.6( \pm 2.5)$ & $2.7( \pm 4.3)$ & 0.001 \\
\hline $\begin{array}{l}\text { Admission temperature } \\
\left({ }^{\circ} \mathrm{C}\right)\end{array}$ & $37.7( \pm 3.9)$ & $37.5( \pm 0.8)$ & $37.5( \pm 0.9)$ & $37.5( \pm 0.6)$ & 0.779 \\
\hline $\begin{array}{l}\text { Systolic blood pressure } \\
(\mathrm{mmHg})\end{array}$ & $130( \pm 17)$ & $127( \pm 16)$ & $136( \pm 19)$ & $131( \pm 19)$ & $<0.001$ \\
\hline $\begin{array}{l}\text { Diastolic blood pressure } \\
(\mathrm{mmHg})\end{array}$ & $81( \pm 12)$ & $81( \pm 11)$ & $83( \pm 14)$ & $69( \pm 10)$ & $<0.001$ \\
\hline Oxygen saturation (\%) & $98( \pm 3)$ & $98( \pm 1)$ & $98( \pm 3)$ & $94( \pm 9)$ & $<0.001$ \\
\hline Pulse rate (per min) & $94( \pm 19)$ & $95( \pm 19)$ & $93( \pm 19)$ & $88( \pm 12)$ & 0.202 \\
\hline Respiratory rate (per min) & $19( \pm 7)$ & $19( \pm 6)$ & $19( \pm 7)$ & $21( \pm 6)$ & 0.378 \\
\hline \multicolumn{6}{|c|}{ Baseline laboratory investigations } \\
\hline $\begin{array}{l}\text { Total White Cell Count } \\
\left(\times 10^{9} / \mathrm{L}\right)\end{array}$ & $6.5( \pm 2.2)$ & $6.5( \pm 1.9)$ & $6.4( \pm 2.6)$ & $6.7( \pm 3.5)$ & 0.810 \\
\hline $\begin{array}{l}\text { Absolute neutrophil } \\
\text { count }\left(\times 10^{9} / \mathrm{L}\right)\end{array}$ & $4.18( \pm 7.9)$ & $4.20( \pm 9.47)$ & $4.07( \pm 2.76)$ & $4.79( \pm 3.29)$ & 0.937 \\
\hline $\begin{array}{l}\text { Absolute lymphocyte } \\
\text { count }\left(\times 10^{9} / L\right)\end{array}$ & $1.90( \pm 2.02)$ & $2.01( \pm 2.35)$ & $1.72( \pm 0.97)$ & $1.18( \pm 0.43)$ & 0.106 \\
\hline Haemoglobin (g/dL) & $14.9( \pm 1.6)$ & $15.1( \pm 1.5)$ & $14.4( \pm 1.6)$ & $13.0( \pm 2.3)$ & $<0.001$ \\
\hline Platelet Count $\left(\times 10^{9} / \mathrm{L}\right)$ & $228( \pm 60)$ & $231( \pm 29)$ & $221( \pm 62)$ & $225( \pm 71)$ & 0.200 \\
\hline Sodium (mmol/L) & $138( \pm 3)$ & $138( \pm 2)$ & $138( \pm 3)$ & $134( \pm 5)$ & 0.076 \\
\hline Urea (mmol/L) & $3.9( \pm 2.6)$ & $3.7( \pm 2.7)$ & $4.0( \pm 1.5)$ & $7.7( \pm 5.5)$ & $<0.001$ \\
\hline Creatinine (mmol/L) & $79( \pm 30)$ & $77( \pm 15)$ & $81( \pm 46)$ & $108( \pm 61)$ & $<0.001$ \\
\hline AST (units/L) & $38( \pm 48)$ & $37( \pm 25)$ & $40( \pm 81)$ & $50( \pm 28)$ & 0.543 \\
\hline ALT (units/L) & $46( \pm 44)$ & $48( \pm 40)$ & $41( \pm 52)$ & $37( \pm 24)$ & 0.234 \\
\hline LDH (units/L) & $436( \pm 423)$ & $412( \pm 408)$ & $477( \pm 462)$ & $630( \pm 279)$ & 0.087 \\
\hline C-reactive protein (mg/L) & $14( \pm 27)$ & 10. $( \pm 23)$ & $19( \pm 29)$ & $65( \pm 61)$ & $<0.001$ \\
\hline Ferritin (ug/L) & $179( \pm 216)$ & $139( \pm 91)$ & $263( \pm 348)$ & $438( \pm 383)$ & $<0.001$ \\
\hline \multicolumn{6}{|l|}{ Clinical outcomes } \\
\hline Pneumonia & $57(10.3 \%)$ & $16(4.3 \%)$ & $33(19.9 \% 0$ & $8(50.0 \%)$ & $<0.001$ \\
\hline $\begin{array}{l}\text { Requiring supplemental } \\
\text { oxygen }\end{array}$ & $16(2.9 \%)$ & $6(1.6 \%)$ & $8(4.8 \%)$ & $2(12.5 \%)$ & 0.008 \\
\hline Persistent fever $>72 \mathrm{~h}$ & $40(7.3 \%)$ & $16(4.3 \%)$ & $21(12.7 \%)$ & $3(20.0 \%)$ & $<0.001$ \\
\hline Acute kidney injury & $45(8.1 \%)$ & $23(6.2 \%)$ & $13(7.8 \%)$ & $9(56.3 \%)$ & $<0.001$ \\
\hline $\begin{array}{l}\text { Required intensive care } \\
\text { monitoring }\end{array}$ & $19(3.4 \%)$ & $3(8.8 \%)$ & $11(6.7 \%)$ & $5(31.3 \%)$ & $<0.001$ \\
\hline $\begin{array}{l}\text { Required mechanical } \\
\text { ventilation }\end{array}$ & $16(2.9 \%)$ & $2(0.5 \%)$ & $9(5.4 \%)$ & $5(31.3 \%)$ & $<0.001$ \\
\hline
\end{tabular}


Table 1 (continued)

\begin{tabular}{|c|c|c|c|c|c|}
\hline Parameter & Overall $(n=554)$ & Age $\leq 40$ years $(n=372)$ & $\begin{array}{l}\text { Age } 41 \text { to } 64 \text { years } \\
(n=166)\end{array}$ & Age $\geq 65$ years $(n=16)$ & p-value \\
\hline $\begin{array}{l}\text { Myocarditis/myocardial } \\
\text { injury }\end{array}$ & $3(0.7 \%)$ & $0(0.0 \%)$ & $2(1.6 \%)$ & $1(20.0 \% 0$ & $<0.001$ \\
\hline Death & $2(0.5 \%)$ & $0(0.0 \%)$ & $0(0.0 \%)$ & $2(33.3 \%)$ & $<0.001$ \\
\hline \multicolumn{6}{|l|}{ Clinical risk scores } \\
\hline $\begin{array}{l}\text { CURB-65 Score (median, } \\
\text { interquartile range) }\end{array}$ & $0(0-0)$ & $0(0-0)$ & $0(0-0)$ & $1(1-2)$ & $<0.001$ \\
\hline $\begin{array}{l}\text { Pneumonia Severity Index } \\
\text { (median, interquartile } \\
\text { range) }\end{array}$ & $35(28-45)$ & $30(27-35)$ & $39(42-53)$ & $68(65-75)$ & $<0.001$ \\
\hline $\begin{array}{l}\mathrm{CHA}_{2} \mathrm{DS}_{2}-\mathrm{VASC} \text { Score } \\
\text { (median, interquartile } \\
\text { range) }\end{array}$ & $0(0-0)$ & $0(0-0)$ & $0(0-1)$ & $1(1-2)$ & $<0.001$ \\
\hline COVID-GRAM Score (\%) & $0.0218(0.0123-0.500)$ & $0.0153(0.0112-0.500)$ & $0.0636(0.0204-0.500)$ & $0.500(0.500-0.500)$ & $<0.001$ \\
\hline VACO Score $(\%)$ & $0.00403(0.00403-0.500)$ & $0.0153(0.0112-0.500)$ & $0.0636(0.004-0.5000)$ & $0.500(0.182-0.500)$ & $<0.001$ \\
\hline 4C Score & $2(1-3)$ & $1(1-2)$ & $2(1-3)$ & $3(2-6)$ & $<0.001$ \\
\hline "Rule-of-6"Score & $0(0-0)$ & $0(0-0)$ & $0(0-0)$ & $2(1-2)$ & $<0.001$ \\
\hline
\end{tabular}

AST: aspartate transaminase; ALT: alanine transaminase; LDH: lactate dehydrogenase; CURB-65: (confusion, blood urea $>42,8 \mathrm{mg} / \mathrm{dl}$, respiratory rate $>30 / \mathrm{min}$, blood pressure $<90 / 60 \mathrm{~mm} \mathrm{Hg}$, age $>65$ ); $\mathrm{CHA}_{2} \mathrm{DS}_{2}$-VASc: Congestive heart failure, Hypertension, Age $\geq 75$ years (doubled), Diabetes mellitus, Prior Stroke or TIA or thromboembolism (doubled), Vascular disease, Age 65-74 years, Sex category; HF: heart failure; LV: left ventricular; MI: myocardial infarction; PAD: peripheral artery disease; TE: thromboembolism; TIA: transient ischemic attack. VACO: Veterans Health administration COVID-19; 4C: Coronavirus Clinical Characterization Consortium

\section{Results}

Of the 554 consecutive patients diagnosed with COVID-19 examined, the majority $(n=372,67.1 \%)$ were $\leq 40$ years old, $30.0 \%(n=166)$ were $40-64$ years old and the remaining $2.9 \%(n=16)$ were $\geq 65$ years old. Most patients did not have medical comorbidities. Patients $\leq 40$ years old were also more likely to be asymptomatic when compared with those aged $41-64$ and $\geq 65$ years old ( $14.0 \%$ asymptomatic compared with $8.4 \%$ and $0.0 \%$ respectively). Patients $\geq 65$ years old tended to present later in their illness, with a longer duration of fever and with lower oxygen saturations (Table 1). The proportion of patients with radiographic evidence of pneumonia was highest in the oldest patients ( $\geq 65$ years, $n=8,50.0 \%$ ), when compared with those aged 41-64 (19.9\%) and $\leq 40$ years old (4.3\%). With increasing age, patients were also more likely to require supplemental oxygen (up to $12.5 \%$ in those $\geq 65$ years old), intensive care and mechanical ventilation (up to $31.3 \%$ in those $\geq 65$ years old). The two deaths in our cohort both occurred in patients $\geq 65$ years of age (Table 1 ).

The median score (with interquartile range) for each age category is shown in Table 1 . Of the 7 scores studied, 4C Score, Rule-of-6, PSI and $\mathrm{CHA}_{2} \mathrm{DS}_{2}$-VASc Score all had an AUC of 0.87 in predicting patients who required an ICU admission, and the CURB-65 score performed the poorest with an AUC of 0.72 (95\% CI 0.57-0.86) (Fig. 1).
In predicting the risk of requiring mechanical ventilation, the $\mathrm{CHA}_{2} \mathrm{DS}_{2}$-VASc Score performed the best with an AUC of 0.89 (95\% CI 0.82-0.97), with other scores ranging between an AUC of 0.80 to 0.87 , however once again the CURB-65 score performed poorly with an AUC of 0.76 (95\% CI 0.61-0.92, Fig. 2).

Finally, all scores, comparatively, underperformed in predicting patients who required supplemental oxygen. The best performing score was the $4 \mathrm{C}$ score with an AUC 0.78 (95\% CI 0.68-0.89, p $<0.001)$, with 4 other scores meeting the threshold for statistical significance: PSI AUC 0.72 (95\% CI 0.60-0.85, $\mathrm{p}=0.002$ ); $\mathrm{CHA}_{2} \mathrm{DS}_{2}$-VASc Score AUC 0.71 (95\% CI 0.56-0.86, $\mathrm{p}=0.005)$; "Rule-of-6" score AUC 0.67 (95\% CI 0.510.83, $\mathrm{p}=0.020)$; COVID-GRAM AUC 0.66 (95\% CI 0.56-0.77, $\mathrm{p}=0.026)$. VACO and CURB-65 scores did not meet statistical significance (Fig. 3). Adding the presence of fever (1 point) to existing scores such as the $\mathrm{CHA}_{2} \mathrm{DS}_{2}$-VASc Score and $4 \mathrm{C}$ score improved the ability of the scores to predict patients who required supplemental oxygen $\left(\mathrm{CHA}_{2} \mathrm{DS}_{2}\right.$-VASc AUC 0.81 (95\% CI 0.68-0.94) and 4C AUC 0.84 (95\% CI 0.75-0.94) respectively) (Fig. 4).

\section{Discussion}

Large and repeated outbreaks of COVID-19 continue to place a strain on healthcare institutions and intensive care facilities [10]. A simple and effective clinical risk score could prove to be invaluable in determining which patients with COVID-19 in the community are likely to 

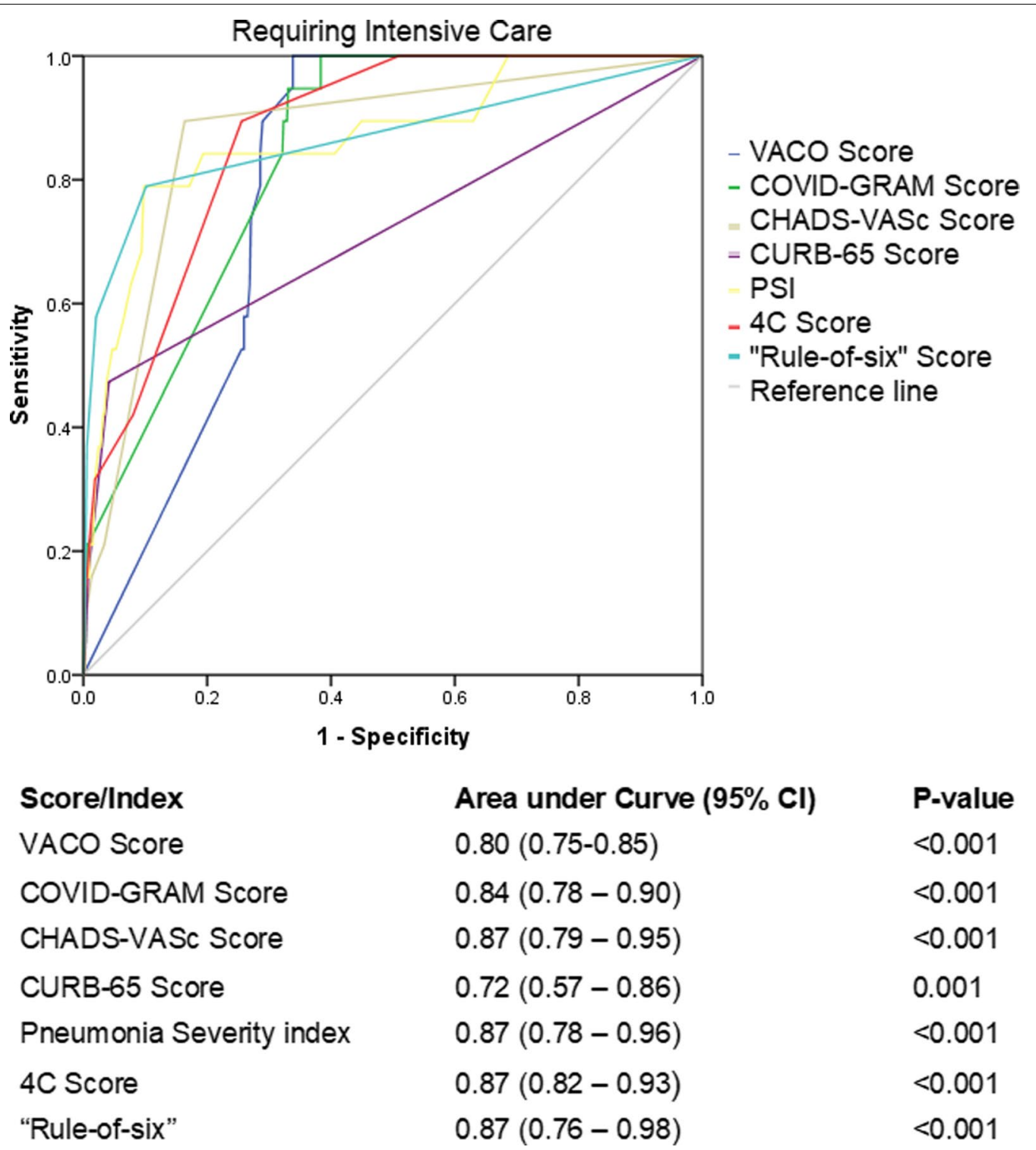

Area under Curve $(95 \% \mathrm{Cl})$
$0.80(0.75-0.85)$
$0.84(0.78-0.90)$
$0.87(0.79-0.95)$
$0.72(0.57-0.86)$
$0.87(0.78-0.96)$
$0.87(0.82-0.93)$
$0.87(0.76-0.98)$

P-value
$<0.001$
$<0.001$
$<0.001$
0.001
$<0.001$
$<0.001$
$<0.001$

Fig. 1 Receiver operating characteristic curve of clinical risk scores in predicting need for intensive care

require oxygen supplementation and therefore would benefit from monitoring in hospital and the initiation of COVID-19 specific therapeutics as early as when they first require oxygen supplementation, i.e. at the juncture of disease severity when they are most likely to benefit [20]. Yet such a definitive tool for COVID-19, that does not require complex laboratory tests, remains elusive [21].

We evaluated 4 risk scores which were developed to predict risk of critical illness or death specifically in patients with COVID-19. This includes the COVIDGRAM score, developed and validated in large Chinese cohorts of patients [13], the $4 \mathrm{C}$ score was derived and validated by cohorts in the United Kingdom [10], the VACO score [12], validated in multiple large American cohorts [22], and finally the Rule-of -6 score developed from a small cohort in Singapore [11]. Of these 4 scores, all required laboratory tests or radiography or both, except for the VACO score, which incorporates the Charlson Comorbidity Index [23], a complex index which requires substantial knowledge of a patient's past medical history. Additional file 1: Table S1 shows the complexity of the score calculation across the risk scores analysed in this study.

Additionally, we evaluated three non-COVID specific tests. The $\mathrm{CHA}_{2} \mathrm{DS}_{2}$-VASc score was originally 


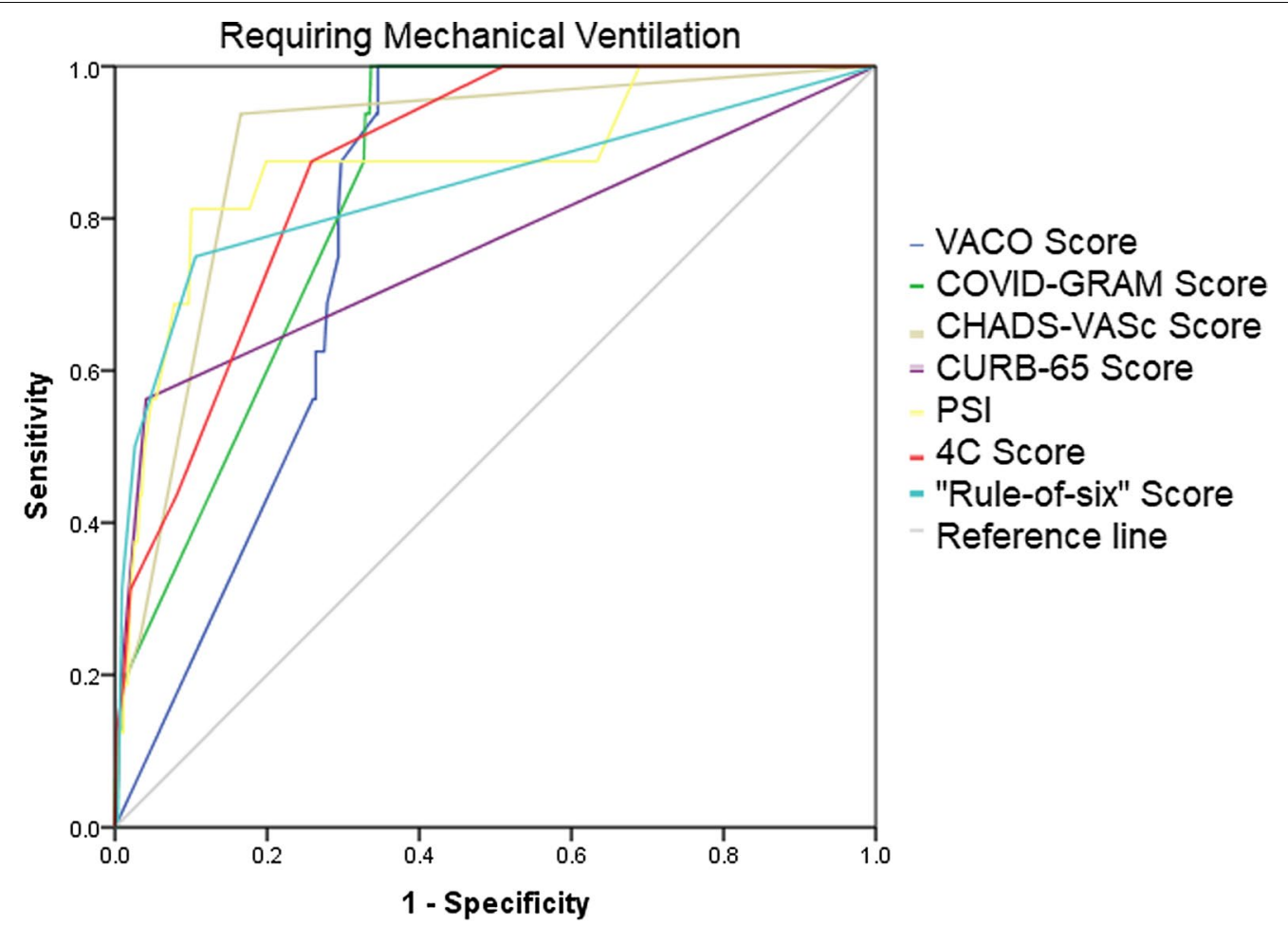

$\begin{array}{lll}\text { Score/Index } & \text { Area under Curve }(95 \% \mathrm{Cl}) & \text { P-value } \\ \text { VACO Score } & 0.80(0.74-0.85) & <0.001 \\ \text { COVID-GRAM Score } & 0.84(0.78-0.90) & <0.001 \\ \text { CHADS-VASc Score } & 0.89(0.82-0.97) & <0.001 \\ \text { CURB-65 Score } & 0.76(0.61-0.92) & <0.001 \\ \text { Pneumonia Severity index } & 0.87(0.77-0.98) & <0.001 \\ \text { 4C Score } & 0.87(0.82-0.93) & <0.001 \\ \text { "Rule-of-six" } & 0.84(0.71-0.97) & <0.001\end{array}$

Fig. 2 Receiver operating characteristic curve of clinical risk scores in predicting need for mechanical ventilation

developed to describe the risk of stroke in patients with atrial fibrillation [4], was the only score tested which was not developed for a pneumonic illness, and also did not require either laboratory tests or radiography. The score has previously been shown to be associated with mortality in hospitalised patients with COVID-19 in two other cohorts, including the current cohort of patients $[18,19]$.

The performance of the evaluated scores revealed that all scores performed well in predicting the severe end of the disease spectrum of COVID-19. This is not unsurprising given that most of these scores were developed to predict mortality or critical illness, the risks factors of which are largely consistent across disease spectrums and even epidemiological cohorts. The $\mathrm{CHA}_{2} \mathrm{DS}_{2}$-VASc score performed well in predicting those patients at risk of ICU admission and also those who were at risk of mechanical ventilation. The $\mathrm{CHA}_{2} \mathrm{DS}_{2}$-VASc score is note-worthy since it does not require any biochemical markers or radiography, and requires basic knowledge of cardiovascular medical history, along with age and sex. The presence of hypertension, diabetes, congestive cardiac failure, previous ischaemic heart disease, and stroke which increase the $\mathrm{CHA}_{2} \mathrm{DS}_{2}$-VASc score have been strongly associated with adverse outcomes in patients with COVID-19 [24].

Indeed, even after adjusting for age, the presence of hypertension as a comorbidity had been one of the earliest identified risk factors for severe COVID-19 illness [25]. Additionally patients with diabetes mellitus have 


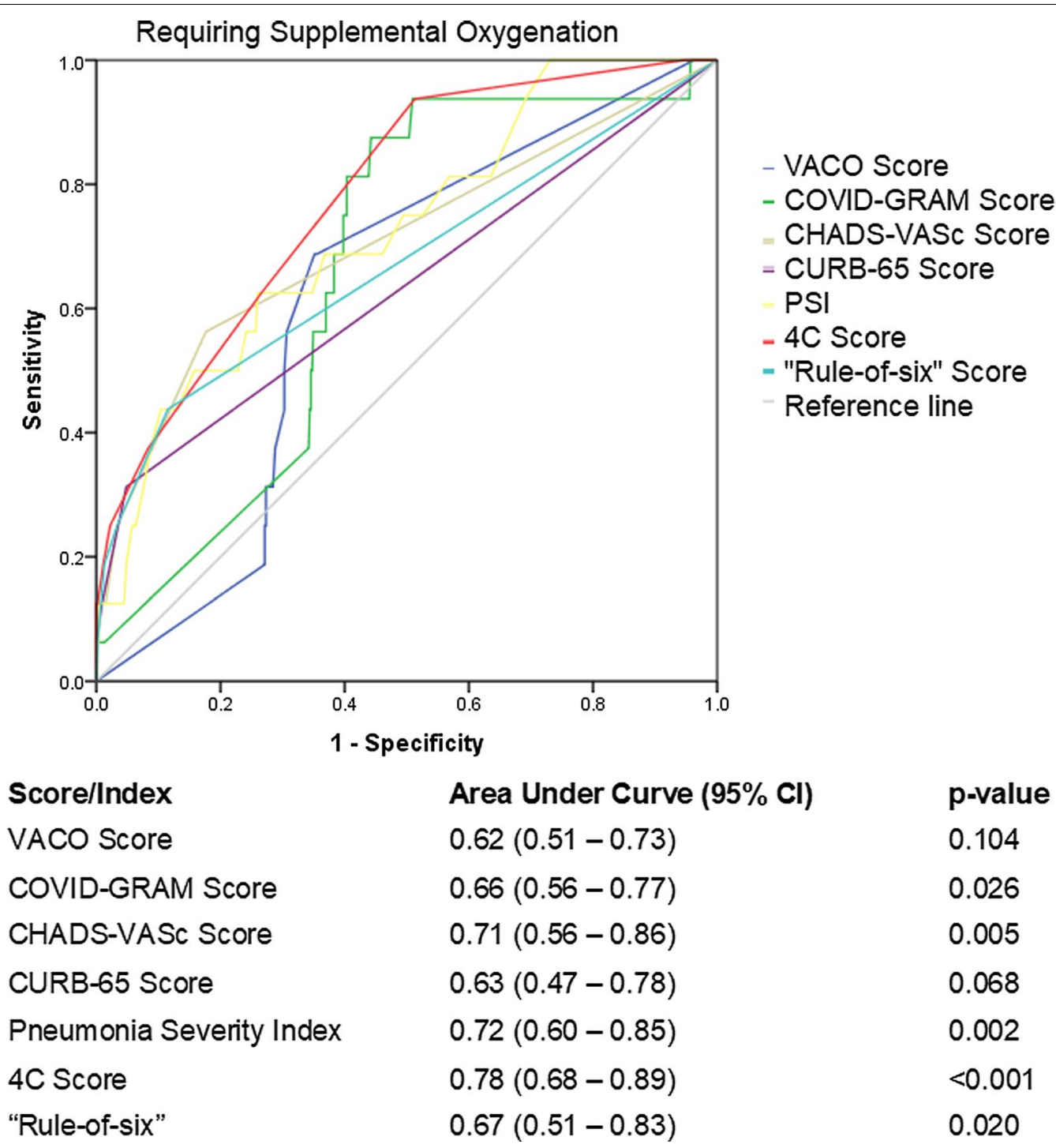

Fig. 3 Receiver operating characteristic curve of clinical risk scores in predicting need for supplemental oxygen

consistently had poorer outcomes in COVID-19 illness [26]. Hyperglycaemia at presentation with underlying poor diabetes control has been shown to be associated with a four-fold increase in mortality compared with those with normoglycaemia [27]. Patients with existing ischaemic heart disease were more likely to present with elevated troponins during their COVID-19 illness, suggesting the presence of myocardial injury, which has been independently associated with adverse clinical outcomes and mortality [28]. The predictive value of the $\mathrm{CHA}_{2} \mathrm{DS}_{2}$-VASc score, might lie in the unique pathology associated with critical COVID-19 disease wherein vascular phenomena are thought to contribute substantially to multi-organ failure and ultimately death [29].
All scores performed less well in predicting those who needed supplemental oxygen therapy. The best performing score in this regard was the $4 \mathrm{C}$, which requires both urea, C-reactive protein, a lymphocyte count as well as a Chest-X-ray to determine the presence of pneumonia. The PSI and the $\mathrm{CHA}_{2} \mathrm{DS}_{2}$-VASc score were found to have AUCs of 0.72 and 0.71 respectively in predicting risk to needing supplemental oxygen, but with relatively wide confidence intervals, which might undermine their performance in some instances. However, adding the presence or absence of fever, a parameter that is readily available in nearly all patients, to the $\mathrm{CHA}_{2} \mathrm{DS}_{2}$-VASc and the $4 \mathrm{C}$ score significantly improved the ability of the 


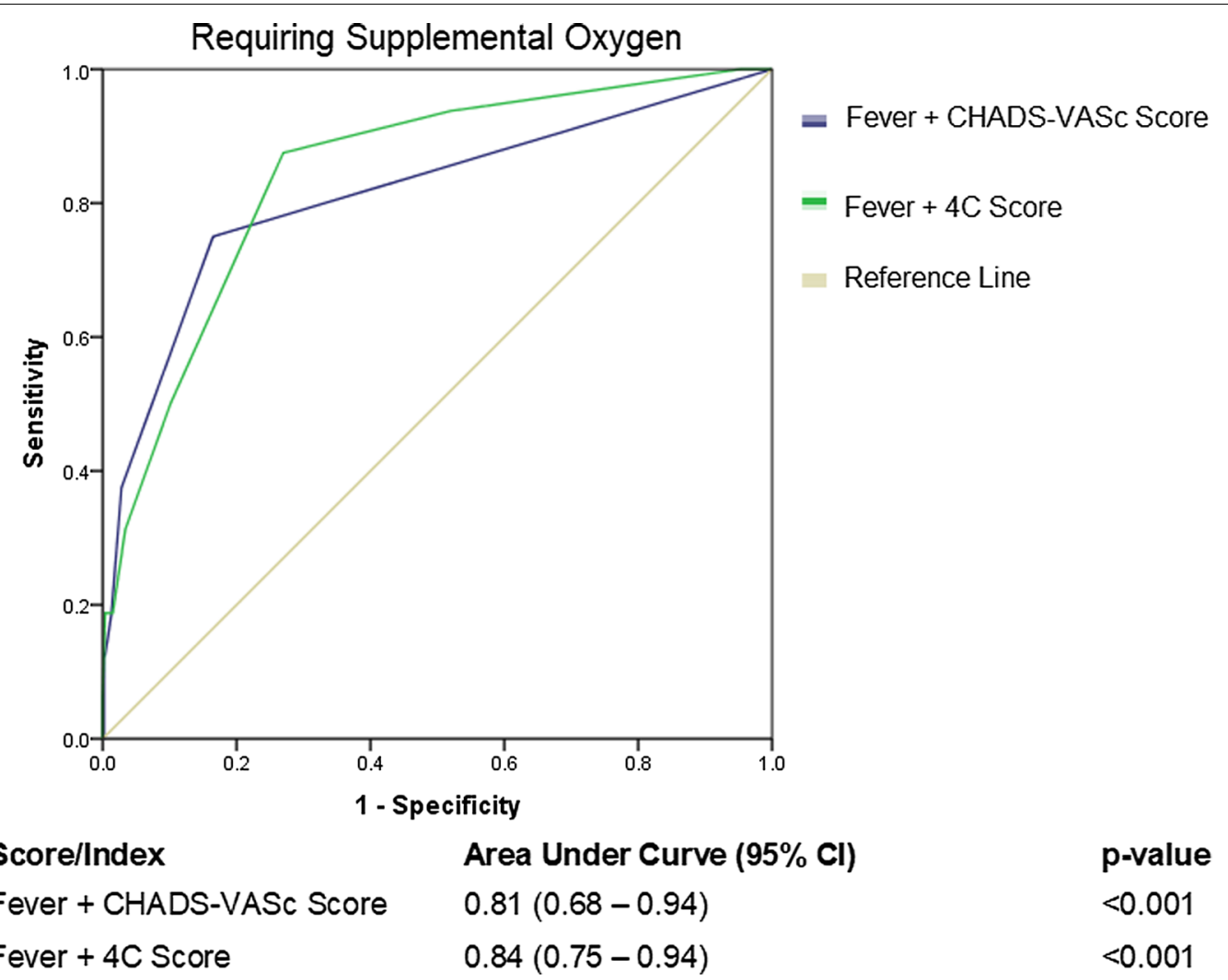

Fig. 4 Receiver operating characteristic curve shows improved performance with the addition of the presence of fever in two clinical risk scores predicting need for supplemental oxygen

scores to predict patients who required supplemental oxygenation.

We have previously shown that both the $\mathrm{CHA}_{2} \mathrm{DS}_{2}$-VASc score and the presence of fever individually were associated with adverse outcomes in COVID$19[3,18,19]$. Here we show that when we combine the both to develop a composite score, it better predicts the need for supplemental oxygenation, even in our relatively low-risk cohort of hospitalised patients with COVID-19.

\section{Limitations}

Our study was based on the experience of a single-centre, moderately-sized cohort of patients diagnosed with COVID-19 in Singapore. Risk scores were tabulated based on information at the time of hospital admission and we did not have access to include data from a small group of patients who were assessed in the emergency department were deemed not to require hospitalisation, and were managed in isolation facilities in the community. It would be important for the findings from our study, namely the performance of the $\mathrm{CHA}_{2} \mathrm{DS}_{2}$-VASc and fever be evaluated in more diverse epidemiological cohorts and in different economies worldwide.

\section{Conclusions}

We evaluated 7 risk scores in patients with COVID-19 to identify those at risk of critical illness or supplemental oxygen. Most require laboratory investigations and may be difficult to apply in an outpatient setting or for immediate triage. We found that both simple scores as well as more well-established disease risk scores can help predict progression of COVID-19. Adding the presence of fever as a parameter to the $\mathrm{CHA}_{2} \mathrm{DS}_{2}$-VASc or the $4 \mathrm{C}$ score improved the performance of these scores in predicting adverse outcomes in relatively young patients with few medical co-morbidities.

\section{Abbreviations}

4C: ISARIC 4C prognostic score; ANOVA: Analysis of variance; ARDS: Acute respiratory distress syndrome; AUC: Area under receiver operating characteristic curve; COVID-19: Coronavirus disease 2019; DSRB: Domain-Specific Review Board; ICU: Intensive care unit; MOF: Multi-organ failure; NHG: National Healthcare Group, Singapore; PSI: Pneumonia severity index; RT-PCR: Reverse transcriptase polymerase chain reaction; VACO: Veteran's Health Administration COVID-19 index for COVID-19 mortality. 


\section{Supplementary Information}

The online version contains supplementary material available at https://doi. org/10.1186/s12879-021-06768-3.

Additional file 1: Supplementary Table S1. Components of commonly used risk scores in the context of COVID-19 illness.

\section{Acknowledgements}

Not applicable.

\section{Authors' contributions}

JNN, NWSC, SMT, ZYL, TYWL, SC and CHS were involved in the conception, data collection, data analysis, and writing of the manuscript. PAT, AS, GBC were involved in the conception, data analysis, and critical review of the manuscript. All authors read and approved the final manuscript.

\section{Funding/support}

There was no funding for this study. CHS was supported by the National University of Singapore Yong Loo Lin School of Medicine's Junior Academic Faculty Scheme; GBC is supported by the NUHS Clinician Scientist Program (NCSP) award.

\section{Availability of data and materials}

Data may be made available on reasonable request from the corresponding author.

\section{Declarations}

\section{Ethics approval and consent to participate}

This study was approved by the hospital's institutional review board (National Healthcare Group (NHG) Domain Specific Review Board (DSRB) 2020/00545). Retrospective analyses were performed and non-identifiable, anonymise data is presented. A waiver of informed consent was obtained from DSRB prior to the conduct of the study. All study methods were carried out in accordance with relevant guidelines and regulations by the Declaration of Helsinki and DSRB.

\section{Consent for publication}

Not applicable (participant information is not published in this manuscript).

\section{Competing interests}

The authors declare no competing interests.

\section{Author details}

${ }^{1}$ Department of Medicine, National University Health System, Singapore, Singapore. ${ }^{2}$ Department of Cardiology, National University Heart Centre Singapore, Singapore, Singapore. ${ }^{3}$ Department of Infectious Diseases, National University Health System, 1 E Kent Ridge Rd, NUHS Tower Block, Level 10, Singapore 119228 , Singapore. ${ }^{4}$ Department of Rheumatology, National University Health System, Singapore, Singapore. ${ }^{5}$ Department of Medicine, Yong Loo Lin School of Medicine, National University of Singapore, Singapore, Singapore. ${ }^{6}$ Infectious Diseases Translational Research Programme, Department of Medicine, Yong Loo Lin School of Medicine, National University of Singapore, Singapore, Singapore.

Received: 23 March 2021 Accepted: 5 October 2021 Published online: 24 October 2021

\section{References}

1. WHO Coronavirus Disease (COVID-19) dashboard. https://covid19.who. int/. Accessed 24 Feb 2021.

2. Byambasuren O, Cardona M, Bell K, Clark J, Mclaws ML, Glasziou P. Estimating the extent of asymptomatic COVID-19 and its potential for community transmission: Systematic review and meta-analysis. Off J Assoc Med Microbiol Infect Dis Can. 2020;5(4):223-34.
3. Chew NWS, Ngiam JN, Tham SM, Lim ZY, Li TYW, Cen S, Yap ES, Tambyah PA, Santosa A, Cross GB, Sia CH. Fever as a predictor of adverse outcomes in COVID-19. QJM Int J Med. 2021. https://doi.org/10.1093/qjmed/hcab0 23.

4. Lip GY, Nieuwlaat R, Pisters R, Lane DA, Crijns HJ. Refining clinical risk stratification for predicting stroke and thromboembolism in atrial fibrillation using a novel risk factor-based approach: the euro heart survey on atrial fibrillation. Chest. 2010;137(2):263-72. https://doi.org/10.1378/ chest.09-1584 (Epub 2009 Sep 17).

5. Lim WS, van der Eerden MM, Laing R, et al. Defining community acquired pneumonia severity on presentation to hospital: an international derivation and validation study. Thorax. 2003;58(5):377-82. https://doi.org/10. 1136/thorax.58.5.377.

6. Fine MJ, Auble TE, Yealy DM, Hanusa BH, Weissfeld LA, Singer DE, Coley CM, Marrie TJ, Kapoor WN. A prediction rule to identify low-risk patients with community-acquired pneumonia. N Engl J Med. 1997;336(4):243-50. https://doi.org/10.1056/NEJM199701233360402.

7. Kalii AC, Patterson TF, Mehta AK, Tomashek KM, Wolfe CR, Ghazaryan V, Marconi VC, Ruiz-Palacios GM, Hsieh L, Kline S, Tapson V, lovine NM, Jain MK, Sweeney DA, El Sahly HM, Branche AR, Regalado Pineda J, Lye DC, Sandkovsky U, Luetkemeyer AF, Cohen SH, Finberg RW, Jackson PEH, Taiwo B, Paules Cl, Arguinchona H, Goepfert P, Ahuja N, Frank M, Oh MD, Kim ES, Tan SY, Mularski RA, Nielsen H, Ponce PO, Taylor BS, Larson L, Rouphael NG, Saklawi Y, Cantos VD, Ko ER, Engemann JJ, Amin AN, Watanabe M, Billings J, Elie MC, Davey RT, Burgess TH, Ferreira J, Green M, Makowski M, Cardoso A, de Bono S, Bonnett T, Proschan M, Deye GA, Dempsey W, Nayak SU, Dodd LE, Beigel JH, ACTT-2 Study Group Members. Baricitinib plus remdesivir for hospitalized adults with Covid-19. N Engl J Med. 2020. https://doi.org/10.1056/NEJMoa2031994.

8. Beigel JH, Tomashek KM, Dodd LE, Mehta AK, Zingman BS, Kalil AC, Hohmann E, Chu HY, Luetkemeyer A, Kline S, Lopez de Castilla D, Finberg RW, Dierberg K, Tapson V, Hsieh L, Patterson TF, Paredes R, Sweeney DA, Short WR, Touloumi G, Lye DC, Ohmagari N, Oh MD, Ruiz-Palacios GM, Benfield T, Fätkenheuer G, Kortepeter MG, Atmar RL, Creech CB, Lundgren J, Babiker AG, Pett S, Neaton JD, Burgess TH, Bonnett T, Green M, Makowski M, Osinusi A, Nayak S, Lane HC, ACTT-1 Study Group Members. Remdesivir for the treatment of Covid-19-final report. N Engl J Med. 2020;383(19):1813-26. https://doi.org/10.1056/NEJMoa2007764 (Epub 2020 Oct 8).

9. RECOVERY Collaborative Group, Horby P, Lim WS, Emberson JR, Mafham M, Bell JL, Linsell L, Staplin N, Brightling C, Ustianowski A, Elmahi E, Prudon B, Green C, Felton T, Chadwick D, Rege K, Fegan C, Chappell LC, Faust SN, Jaki T, Jeffery K, Montgomery A, Rowan K, Juszczak E, Baillie JK, Haynes $\mathrm{R}$, Landray MJ. Dexamethasone in hospitalized patients with Covid-19preliminary report. N Engl J Med. 2020. https://doi.org/10.1056/NEJMo a2021436 (Epub ahead of print).

10. Docherty AB, Harrison EM, Green CA, Hardwick HE, Pius R, Norman L, Holden KA, Read JM, Dondelinger F, Carson G, Merson L, Lee J, Plotkin D, Sigfrid L, Halpin S, Jackson C, Gamble C, Horby PW, Nguyen-Van-Tam JS, Ho A, Russell CD, Dunning J, Openshaw PJ, Baillie JK, Semple MG, ISARIC4C investigators. Features of 20133 UK patients in hospital with covid-19 using the ISARIC WHO Clinical Characterisation Protocol: prospective observational cohort study. BMJ. 2020;369:m1985. https://doi. org/10.1136/bmj.m1985.

11. Dickens BSL, Lim JT, Low JW, Lee CK, Sun Y, Nasir HBM, Mohamed Akramullah FA, Yan G, Oon J, Yan B, Sun L, Cook AR, Tambyah PA, Chai LYA. Simple "Rule-of-6" predicts severe coronavirus disease 2019 (COVID-19). Clin Infect Dis. 2020. https://doi.org/10.1093/cid/ciaa938.

12. King JT Jr, Yoon JS, Rentsch CT, Tate JP, Park LS, Kidwai-Khan F, Skanderson M, Hauser RG, Jacobson DA, Erdos J, Cho K, Ramoni R, Gagnon DR, Justice AC. Development and validation of a 30-day mortality index based on pre-existing medical administrative data from 13,323 COVID-19 patients: The Veterans Health Administration COVID-19 (VACO) Index. PLoS ONE. 2020;15(11):e0241825. https://doi.org/10.1371/journal.pone.02418.

13. Liang W, Liang H, Ou L, Chen B, Chen A, Li C, Li Y, Guan W, Sang L, Lu J, Xu Y, Chen G, Guo H, Guo J, Chen Z, Zhao Y, Li S, Zhang N, Zhong N, He J, China Medical Treatment Expert Group for COVID-19. Development and validation of a clinical risk score to predict the occurrence of critical illness in hospitalized patients with COVID-19. JAMA Intern Med. 2020;180(8):1081-9. https://doi.org/10.1001/jamainternmed.2020.2033. 
14. Ngiam JN, Chew N, Tham SM, Beh DLL, Lim ZY, Li TYW, Cen S, Tambyah PA, Santosa A, Sia CH, Cross GB. Demographic shift in COVID-19 patients in Singapore from an aged, at-risk population to young, migrant workers with reduced risk of severe disease. Int J Infect Dis. 2021;103:329-35. https://doi.org/10.1016/j.ijid.2020.11.157.

15. Tan THY, Toh MPHS, Vasoo S, Lye DCB, Ang BSP, Leo YS, Lee VJM, Puah SH, Kurup A. Coronavirus disease 2019 (COVID-19): the Singapore experience. A review of the first eight months. Ann Acad Med Singap. 2020:49(10):764-78.

16. Ioannidis JPA, Axfors C, Contopoulos-loannidis DG. Population-level COVID-19 mortality risk for non-elderly individuals overall and for nonelderly individuals without underlying diseases in pandemic epicenters. Environ Res. 2020;188:109890. https://doi.org/10.1016/j.envres.2020. 109890.

17. Centers for Disease Control and Prevention. Older adults: at greater risk of requiring hospitalization or dying if diagnosed with COVID-19. Published 13 Dec 2020. https://www.cdc.gov/coronavirus/2019-ncov/need-extraprecautions/older-adults.html\#. Accessed 17 Feb 2021.

18. Ruocco G, McCullough PA, Tecson KM, et al. Mortality risk assessment using CHA(2)DS(2)-VASc scores in patients hospitalised with Coronavirus Disease 2019 infection. Am J Cardiol. 2020;137:111-7.

19. Chew N, Ngiam N, Sia CH. The utility of CHA(2)DS(2)-VASc Scores as a risk assessment tool in low risk in-hospital patients with Coronavirus Disease 2019 infection. Am J Cardiol. 2020;141:160-2.

20. Matthay MA, Thompson BT. Dexamethasone in hospitalised patients with COVID-19: addressing uncertainties. Lancet Respir Med. 2020;8(12):11702. https://doi.org/10.1016/S2213-2600(20)30503-8 (Epub 2020 Oct 29).

21. Huang D, Wang T, Chen Z, Yang H, Yao R, Liang Z. A novel risk score to predict diagnosis with coronavirus disease 2019 (COVID-19) in suspected patients: a retrospective, multicenter, and observational study. J Med Virol. 2020;92(11):2709-17.

22. King JT, Yoon JS, Bredl ZM, et al. Accuracy of the Veterans Health Administration COVID-19 (VACO) Index for predicting short-term mortality among 1,307 Yale New Haven Hospital inpatients and 427,224 Medicare patients. medRxiv. Published online Jan 4, 2021:2021.01.01.20249069.

23. Charlson ME, Pompei P, Ales KL, MacKenzie CR. A new method of classifying prognostic comorbidity in longitudinal studies: development and validation. J Chronic Dis. 1987;40(5):373-83. https://doi.org/10.1016/ 0021-9681(87)90171-8.

24. Fisher M. Cardiovascular disease and cardiovascular outcomes in COVID19. Pract Diabetes. 2020;37(5):191-193a. https://doi.org/10.1002/pdi. 2294.

25. Kulkarni S, Jenner BL, Wilkinson I. COVID-19 and hypertension. J Renin Angiotensin Aldosterone Syst. 2020;21(2):1470320320927851. https://doi. org/10.1177/1470320320927851.

26. Apicella M, Campopiano MC, Mantuano M, Mazoni L, Coppelli A, Del Prato S. COVID-19 in people with diabetes: understanding the reasons for worse outcomes. Lancet Diabetes Endocrinol. 2020;8(9):P782-792.

27. Bode B, Garrett V, Messler J, McFarland R, Crowe J, Booth R, Klonoff DC. Glycemic characteristics and clinical outcomes of COVID-19 patients hospitalized in the United States. J Diabetes Sci Technol. 2020;14(4):813-821. https://doi.org/10.1177/1932296820924469. Epub 2020 May 9. Erratum in: J Diabetes Sci Technol. 2020 Jun 10;1932296820932678.

28. Guo T, Fan Y, Chen M, et al. Cardiovascular implications of fatal outcomes of patients with coronavirus disease 2019 (COVID-19). JAMA Cardiol. 2019. https://doi.org/10.1001/jamacardio.2020.1017 (Epub ahead of print 27 March 2020).

29. Siddiqi HK, Libby P, Ridker PM. COVID-19—a vascular disease. Trends Cardiovasc Med. 2021;31(1):1-5. https://doi.org/10.1016/j.tcm.2020.10. 005.

\section{Publisher's Note}

Springer Nature remains neutral with regard to jurisdictional claims in published maps and institutional affiliations.
Ready to submit your research? Choose BMC and benefit from:

- fast, convenient online submission

- thorough peer review by experienced researchers in your field

- rapid publication on acceptance

- support for research data, including large and complex data types

- gold Open Access which fosters wider collaboration and increased citations

- maximum visibility for your research: over $100 \mathrm{M}$ website views per year

At BMC, research is always in progress.

Learn more biomedcentral.com/submissions 